\title{
Fluid bubbles in melt inclusions and pillow-rim glasses: high-temperature precursors to hydrothermal fluids?
}

\author{
V.S. Kamenetsky ${ }^{\mathrm{a}, *}$, P. Davidson ${ }^{\mathrm{a}}$, T.P. Mernagh ${ }^{\mathrm{b}}$, A.J. Crawford ${ }^{\mathrm{a}}$, J.B. Gemmell ${ }^{\mathrm{a}}$, \\ M.V. Portnyagin ${ }^{c}$, R. Shinjo ${ }^{\mathrm{d}}$ \\ ${ }^{a}$ Centre for Ore Deposit Research and School of Earth Sciences, University of Tasmania, GPO Box 252-79, Hobart, Tasmania, 7001, Australia \\ b Australian Geological Survey Organisation, GPO Box 378, Canberra, ACT 2601, Australia \\ ${ }^{\mathrm{c}}$ Vernadsky Institute of Geochemistry, Russian Academy of Science, Kosigin 19, Moscow 117975, Russia \\ ${ }^{\mathrm{d} D e p a r t m e n t}$ of Physics and Earth Sciences, University of the Ryukyus, Senbaru-1, Nishihara, Okinawa 903-0213, Japan
}

\begin{abstract}
Hypotheses for the formation of many types of hydrothermal ore deposits often involve the direct contribution of magmarelated fluids (e.g., $\mathrm{Cu}-\mathrm{Mo}-\mathrm{Au}$ porphyries) or their superimposition on barren hydrothermal cells (e.g., volcanic-hosted massive sulfide deposits). However, the chemical and phase compositions of such fluids remain largely unknown. We report preliminary results of a comprehensive study of fluid bubbles trapped inside glassy melt inclusions in primitive olivine phenocrysts and pillow-rim glasses from basaltic magmas from different tectonic environments, including mid-ocean ridges (Macquarie Island, SW Pacific and Mid-Atlantic Ridge $43^{\circ} \mathrm{N}$ Fracture Zone), ocean islands (Hawaii) and a variety of modern and ancient backarc-island arc settings (eastern Manus Basin, Okinawa and Vanuatu Troughs, Troodos, New Caledonia and Hunter Ridge-Hunter Fracture Zone). Fluid bubbles from all localities, studied using electron microscopy with EDS and laser Raman spectroscopy, are composed of $\mathrm{CO}_{2}-\left( \pm \mathrm{H}_{2} \mathrm{O} \pm\right.$ sulfur)-bearing vapor and contain significant amounts of amorphous $(\mathrm{Na}-\mathrm{K}-\mathrm{Ca}-\mathrm{Fe}$ alumino-silicates and dissorded carbon) and crystalline phases. The crystals are represented mainly by carbonates (magnesite, calcite, ankerite, dolomite, siderite, nahcolite and rhodochrosite), sulfates (anhydrite, gypsum, barite and anglesite), and sulfides (pyrite, arsenopyrite, chalcopyrite and marcasite), though other minerals (brukite, apatite, halite, clinoenstatite, kalsilite, nepheline, amphibole and mica) may occur as well. We argue that chemical components (e.g., C, H, S, $\mathrm{Cl}, \mathrm{Si}, \mathrm{Al}, \mathrm{Na}, \mathrm{K}, \mathrm{Fe}, \mathrm{Mn}, \mathrm{Cr}, \mathrm{Ca}, \mathrm{Mg}, \mathrm{Ba}, \mathrm{Pb}$ and $\mathrm{Cu}$ ) that later formed precipitates in fluid bubbles were originally dissolved in the magmatic fluid, and were not supplied by host glasses or phenocrysts after entrapment. Magma-related fluid rich in dissolved metals and other non-volatile elements may be a potential precursor to ore-forming solutions. (C) 2002 Elsevier Science B.V. All rights reserved.
\end{abstract}

Keywords: Fluid bubble; Melt inclusion; Pillow-rim glass; High-temperature precursor; Hydrothermal fluid

\section{Introduction}

${ }^{*}$ Corresponding author. Tel.: +613-6226-7649; fax: +6136223-2547.

E-mail address: Dima.Kamenetsky@utas.edu.au (V.S. Kamenetsky).
Magma-derived fluids are an essential component of virtually all magmatic systems, especially at low pressure, when silicate melts attain saturation in volatiles. Carbon dioxide, $\mathrm{H}_{2} \mathrm{O}$, and $\mathrm{S}$ gaseous species 
are the most voluminous components in magmatic fluids, and their relative proportions are highly variable, depending on the magma composition, temperature and pressure. For example, the solubility of $\mathrm{CO}_{2}$ in basaltic magmas is strongly reduced at near-surface pressures, in contrast to that of $\mathrm{H}_{2} \mathrm{O}$. In general, degassing starts when a magma reaches saturation in one or more volatiles, and in many cases degassing profoundly affects further magma evolution, the composition of crystallizing phases and the styles of eruption. The composition of the immiscible volatile phase in magmas is well documented through studies of gaseous emissions during volcanic eruptions and fluid inclusions in magmatic phenocrysts and quenched glasses. What still remains unclear is the composition of magmatic fluids, apart from their dominantly $\mathrm{CO}_{2}$ and $\mathrm{H}_{2} \mathrm{O}$ composition. In other words, what other elements are present and in what quantities? The answer to this question may be important in refining our understanding of element transport from magmas into related hydrothermal systems and ultimately, to ore deposits.

The composition and concentration of "non-volatile" components of magmatic fluids has been approached in several ways.

(1) Numerous high-pressure experiments carried out to determine the solubility of major and trace elements in $\mathrm{H}_{2} \mathrm{O}-, \mathrm{H}_{2} \mathrm{O}+\mathrm{CO}_{2}$, and $\mathrm{CO}_{2}$ fluids in equilibrium with mantle minerals and silicate melts (see reviews of experimental data in Eggler, 1987; Candela and Piccoli, 1995; Tatsumi and Eggins, 1995) have shown increased solubility in $\mathrm{H}_{2} \mathrm{O}$-rich fluids. Although these experiments have significant implications for mass transfer in suprasubduction zones and metasomatic processes in the mantle, they are hardly applicable to fluid-melt equilibria at low "subvolcanic" pressures.

(2) Analyses of vapors released during explosive volcanic eruptions (see review in Symonds et al., 1994) give information on the composition of volatile species and elements, including metals, dissolved in gases and associated with aerosols (e.g., Nriagu, 1989; Symonds et al., 1992; Hedenquist et al., 1993; Hinkley et al., 1999) or high-temperature fumaroles (e.g., Hedenquist et al., 1994), presumably during the latest stage of magma evolution. However, the bulk composition of volcanic gases and element ratios may be compromised due to reaction with country rocks, mixing with gases from other sources and condensation of a hypersaline liquid from the vapor.

(3) Optical and microanalytical studies of fluid inclusions in phenocrysts (Sobolev and Nikogosian, 1994) and mantle minerals (Rovetta and Mathez, 1982; Andersen et al., 1984) and fluid-filled vesicles in quenched submarine glasses (Moore and Calc, 1971; Mathez and Yeats, 1976; Yeats and Mathez, 1976; Moore et al., 1977; Alt et al., 1993) and in lavas (de Hoog and van Bergen, 2000) have revealed crystalline (carbonates, silicates, sulfides and chlorides) and amorphous material present on the crystalfluid or glass-fluid interfaces. In most such studies (Moore et al., 1977; Andersen et al., 1984; Alt et al., 1993; Sobolev and Nikogosian, 1994), the origin of solid phases in fluid bubbles was ascribed to the exchange reactions between the volatile components of trapped fluids ( $\mathrm{H}, \mathrm{C}$ and $\mathrm{S})$ and elements from host minerals or melts. An alternative explanation, namely initially high concentrations of $\mathrm{Cu}, \mathrm{Na}$ and $\mathrm{Cl}$ in magmatic vapor, has followed the discovery of copper sulfides in $\mathrm{CO}_{2^{-}}$and Cl-bearing bubbles in phenocryst-hosted melt inclusions (Lowenstern et al., 1991) and salt (halite) crystals in vesicles (Solovova et al., 1991; Lowenstern, 1994a) in the glassy matrix of rhyolites from Pantelleria (Strait of Sicily). Similarly, de Hoog and van Bergen (2000) argue for transport of high-field strength and rare-earth elements, Th and $U$ in magmatic volatile phase based on the presence of zirconolite in vesicles in calcalkaline lavas of Lewotolo volcano, Indonesia. A study of precipitates in fluid bubbles in an andesite-rhyolite suite from the eastern Manus backarc basin (Yang and Scott, 1996) provided the first quantitative estimates of non-gaseous elements in magmatic $\mathrm{CO}_{2}$-rich fluid and made inferences on the direct magmatic contribution to the associated "black smoker"-type hydrothermal activity of the PACMANUS field.

The aim of this paper is to demonstrate that significant quantities of "non-volatile" elements may be dissolved in early magmatic fluids and be available to the ore-forming processes. To cover a larger range of mantle-derived magmas, we have chosen representative samples from mid-ocean and backarc ridges, immature island arcs, and oceanic islands. The methodology applied in this work is in situ microanalysis of 
solid material lining the walls of fluid-filled cavities in submarine glasses and melt inclusions in olivine phenocrysts.

\section{Samples and methods}

The samples used in this study are basaltic to picritic lavas quenched underwater, so the melts, in the form of pillow-rim glasses and melt inclusions in olivine phenocrysts, have largely escaped devitrification. The glassy appearance of melts was imperative in observing and analyzing entrapped fluid bubbles and their solid contents.

Magmatism of mid-ocean ridges is represented by pillow-rim and hyaloclastite basaltic glasses from the Macquarie Island ophiolite, SW Pacific (Kamenetsky et al., 2000), and pillow basalts from the MidAtlantic Ridge in vicinity of $43^{\circ} \mathrm{N}$ Fracture Zone (Kamenetsky et al., 1998). Backarc basin magmas in this study are characterised by olivine + clinopyroxene \pm plagioclase-phyric basalts from the eastern Manus spreading ridge, near PACMANUS hydrothermal field (Binns and Scott, 1993; Kamenetsky et al., 2001), the New Hebrides Troughs, separating the Vanuatu island arc from the active North Fiji basin (Maillet et al., 1995), and the Okinawa Trough formed by extension of continental lithosphere behind the Ryukyu arc-trench system (Shinjo et al., 1999). A variety of primitive arc lavas (olivinebearing arc tholeiites and boninites) are from well known ophiolitic complexes, such as New Caledonia (Cameron, 1989) and Troodos (Sobolev et al., 1993;
Portnyagin et al., 1997), and from the Hunter RidgeHunter Fracture Zone, an aborted embyonic intraoceanic arc along the southern margin of the North Fiji Basin (Sigurdsson et al., 1993). As an example of intraplate oceanic magmatism, a picritic tholeiite from Mauna Loa, HI, was selected.

The samples were crushed and sieved, and glass chips and a large number (100-300) of olivine grains containing melt inclusions were hand picked, mounted in epoxy and analysed for major elements using a Cameca SX-50 electron microprobe (University of Tasmania) and standard analytical procedures. The relatively primitive, unfractionated nature of the studied glasses and olivine phenocrysts is expressed in terms of their $\mathrm{Mg} /\left(\mathrm{Mg}+\mathrm{Fe}^{2+}\right)$ and forsterite content, respectively (Table 1 ).

Laser Raman spectroscopy (Australian Geological Survey Organisation) was applied to determine the phase composition of individual precipitates within fluid bubbles. The spectra were recorded on a Dilor SuperLabram spectrometer equipped with a holographic notch filter, 600 and $1800 \mathrm{~g} / \mathrm{mm}$ gratings, and a liquid $\mathrm{N}_{2}$ cooled, $2000 \times 450$ pixel $\mathrm{CCD}$ detector. The samples were illuminated with 514.5 $\mathrm{nm}$ laser excitation from a Spectra Physics model 2017 argon ion laser, using $5 \mathrm{~mW}$ power at the sample. A $100 \times$ Olympus microscope objective was used to focus the laser beam and collect the scattered light. The focused laser spot on the samples was approximately $1 \mu \mathrm{m}$ in diameter. Wavenumbers are accurate to $\pm 1 \mathrm{~cm}^{-1}$ as determined by plasma and neon emission lines. For the analysis of solid phases and $\mathrm{CO}_{2}$ in the vapor phase, spectra were

Table 1

Phase composition of precipitates inside fluid bubbles in submarine glasses and glassy melt inclusions in olivine phenocrysts

\begin{tabular}{|c|c|c|c|c|c|c|c|c|}
\hline No. & Type locality & Olivine, Fo & Glass, $\mathrm{Mg \#}$ & Carbonates & Sulphates & Sulphides & Silicates & Other \\
\hline 1 & OIB, Mauna Loa, HI & $84-89$ & & $\bullet$ & $\bullet$ & $\bullet$ & & $\bullet$ \\
\hline 2 & MORB, Macquarie Island & & $61-69$ & $\bullet$ & $\bullet$ & $\bullet$ & & $\bullet$ \\
\hline 3 & $\mathrm{MORB}, 43^{\circ} \mathrm{N}$ MAR & $90-92$ & $63-70$ & $\bullet$ & & $\bullet$ & & $\bullet$ \\
\hline 4 & BABB, eastern Manus Basin & $85-91$ & & $\bullet$ & $\bullet$ & $\bullet$ & $\bullet$ & $\bullet$ \\
\hline 5 & BABB, Vanuatu Troughs & $79-89$ & & $\bullet$ & $\bullet$ & & & $\bullet$ \\
\hline 6 & BABB, Okinawa Trough & $85-87$ & & $\bullet$ & & $\bullet$ & & $\bullet$ \\
\hline 7 & ARC, Hunter FZ-Hunter Ridge & $85-92$ & & $\bullet$ & $\bullet$ & $\bullet$ & & $\bullet$ \\
\hline 8 & ARC, New Caledonia & $89-93$ & & $\bullet$ & $\bullet$ & & $\bullet$ & $\bullet$ \\
\hline 9 & ARC, Troodos & $87-91$ & & $\bullet$ & & $\bullet$ & $\bullet$ & $\bullet$ \\
\hline
\end{tabular}

Composition of host olivine phenocrysts (Fo) and submarine glasses $(\mathrm{Mg} \# \mathrm{Mg} /(\mathrm{Mg}+0.9 * \mathrm{Fe})$ are in $\mathrm{mol} \%$.

Other mineral species may be present, but have not been detected yet. 
recorded from 150 to $1800 \mathrm{~cm}^{-1}$ using a single $20 \mathrm{~s}$ integration time per spectrum. Some samples were also checked for $\mathrm{H}_{2} \mathrm{O}, \mathrm{N}_{2}, \mathrm{H}_{2} \mathrm{~S}$ and $\mathrm{CH}_{4}$ in the vapor phase at higher wavenumbers $\left(1000-3800 \mathrm{~cm}^{-1}\right)$ but these gases were below the detection limits. Raman detection limits are dependent on instrumental sensitivity and the partial pressure of each gas but are estimated to be about $0.1 \mathrm{MPa}$ for $\mathrm{CO}_{2}$ and $\mathrm{N}_{2}$, and $0.03 \mathrm{MPa}$ for $\mathrm{H}_{2} \mathrm{~S}$ and $\mathrm{CH}_{4}$.

Electron images and X-ray spectra were collected using an Electroscan ESEM2020 (University of Tasmania) and a JEOL 6400 (Australian National University) instruments equipped with a Link Pentafet SATW Energy Dispersive X-ray detectors. Analytical conditions were $15 \mathrm{kV}$ accelerating voltage and $1 \mathrm{nA}$ beam current.

\section{Results}

Fluid inclusions and bubbles in melt inclusions in olivine and in quenched glasses often show crystalline and amorphous precipitates lining the walls of cavities (internal decoration) and freestanding crystals (Figs. 1-4). The relative volumes of decorations and freestanding crystals vary considerably between inclusions.

\subsection{Morphological types of precipitates}

There are three main types of internal decoration, each with a significantly different distribution within a bubble. These are crystal aggregates, single crystals and continuous mats.

Crystal aggregates (clusters) often appear almost spherical in shape (Figs. 2a,e,f and 4), however they have distinct facets at high magnification. In most cases, this type is represented by opaque material (most likely sulfides; Fig. $4 \mathrm{a}-\mathrm{c}$ ), but other minerals can also occur (Fig. 4d,e). In a given cavity, larger clusters of uniform size $(2-4 \mu \mathrm{m})$ may be surrounded by smaller clusters $(<1 \mu \mathrm{m})$ that form circles at a fixed radius around the larger ones (Fig. 4a,b). Crystal aggregates are partly embedded in the cavity wall in hemispherical pits, which are observed when the cluster drops out (Fig. 4f). Pits project into the host glass and have pockmarked, faceted surfaces. The presence of pits implies that the crystal aggregates were present as solids on the bubble wall, embedded in the meniscus, while the host was still liquid or plastic.

Single crystals are represented by variably sized, individual equant to lath-shaped grains (Figs. 1a,b,e,g,h, 2b-d and 3c,d). The crystals are clear, and some are strongly birefringent. Most single crystals lie flat against the cavity wall, but some project outwards into the glass, possibly analogous to the attachment of crystal aggregates.

Continuous mats are composed of polygonal to round crystals attached to each other and lining large areas of the cavity wall (Figs. 1d,f, $2 \mathrm{~g}$ and $3 \mathrm{~g}$ ). The material making up the mats is translucent and possibly birefringent. Single crystals can be recognised at the outer edges of the mats (Fig. 3g).

Freestanding crystals are seen in both breached and unbreached inclusions. Slightly curved, randomly oriented acicular crystals are typically attached to the bubble walls at both ends, spanning the intervening space (Fig. 3 a,b). Flat lying sheaves of acicular crystals are also noted. Freestanding lath-shaped crystals with acute termination, sometimes in small groups, also project into the interiors of bubbles (Fig. 3h).

\subsection{Distribution of precipitates}

Each of the above decorations has its own distinct pattern of distribution. Crystal aggregates have an even, pseudorandom distribution (Fig. 4), analogous to the form of "bubble rafts", which are the result of surface tension. In some inclusions, aggregates form arcs and bands (Figs. 1c,d and 4e). Single crystals have an apparently random distribution. Pairs and clumps of grains of various sizes are common, as are areas with no crystals. Bi-modal distribution is moderately common, with abundant large crystals at one end and scarce small crystals at the other (Figs. $1 \mathrm{c}-\mathrm{e}, \mathrm{h}$ and 2f). Bubbles in submarine glasses (Fig. 4) contain coexisting crystal aggregates and single crystals; significantly, the former show even, pseudorandom, distribution, whereas most of the single crystals have an apparently random distribution.

In bubbles in glass inclusions, there is a general correlation between bubble to glass ratio for a given inclusion, and the density (amount) of precipitates (Fig. 5, see also Kamenetsky et al., 2001). The bubbles with the smallest volume relative to the 

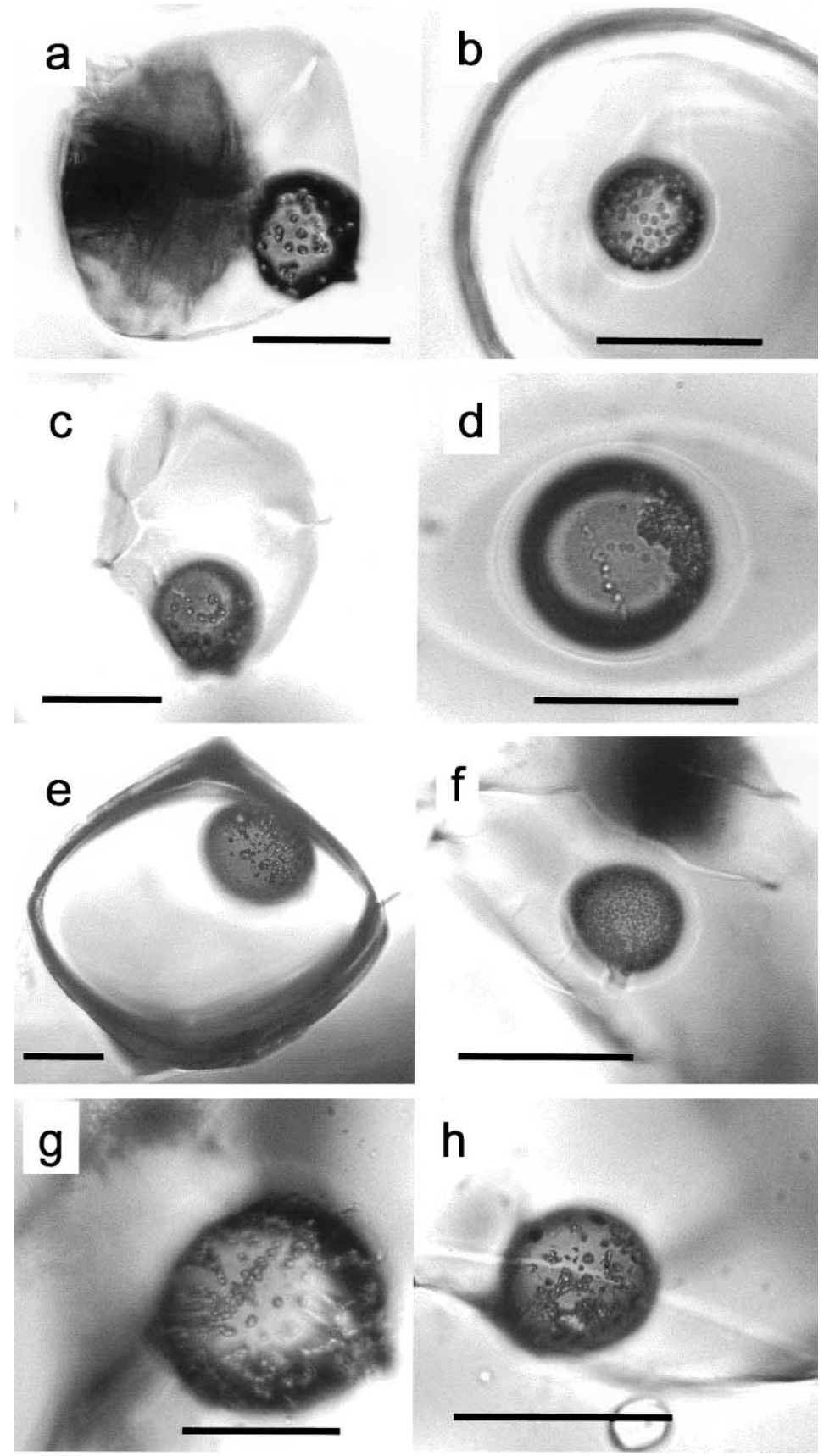

Fig. 1. Precipitates in fluid bubbles in melt inclusions trapped in olivine. (a-c) Hunter Fracture zone-Hunter Ridge; (d, e) eastern Manus Basin; (f) Okinawa Trough; (g) Vanuatu Troughs; (h) Hawaii. Scale bars are $40 \mu \mathrm{m}$.

associated glass carry little or no precipitates and are inferred to be shrinkage bubbles (Fig. 5, inclusion A). Bubbles with greater relative volumes show the greatest amount of precipitates, so that strongly convergent lighting is needed to see within these bubbles (Fig. 5, inclusion B). We interpret these bubbles as 

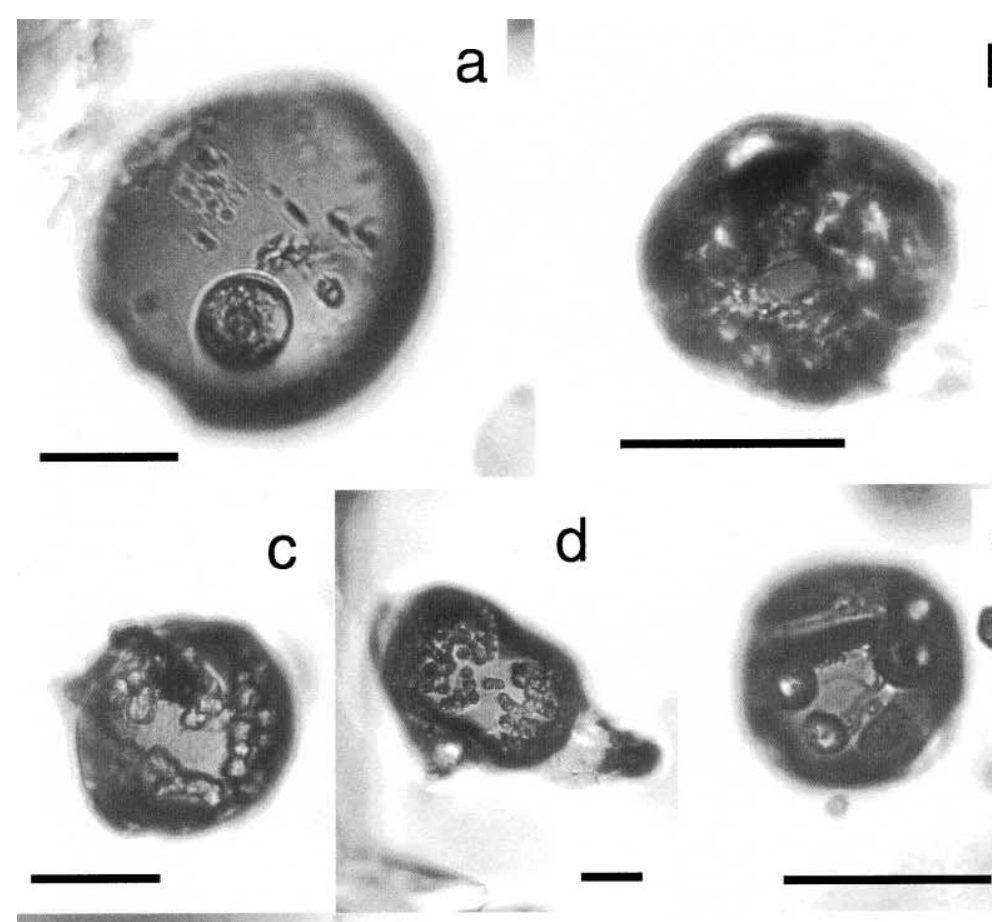

b
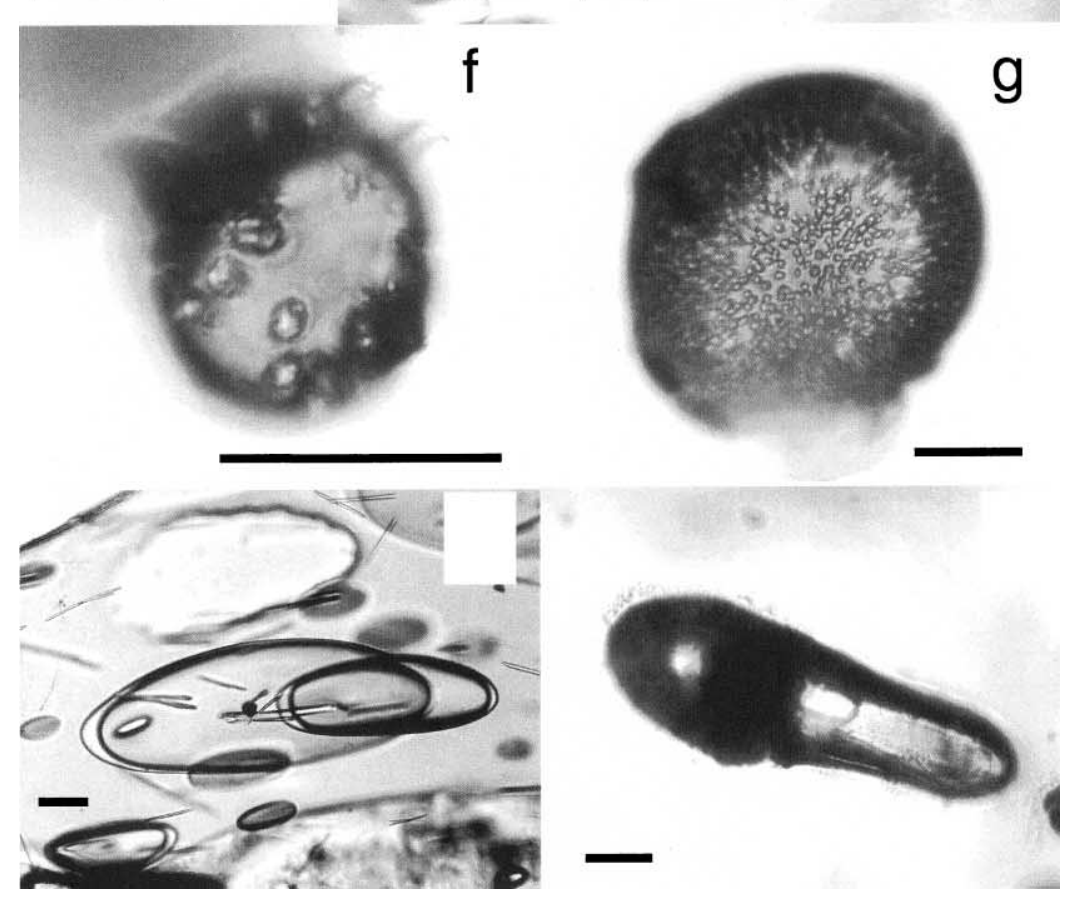

Fig. 2. Precipitates in individual fluid inclusions trapped in olivine $(\mathrm{a}-\mathrm{g})$. (a) Hawaii; (b) eastern Manus Basin; (c-e) Hunter Fracture zoneHunter Ridge; (f, g) $43^{\circ} \mathrm{N}$ mid-Atlantic Ridge. Fluid inclusions with a phase bondary between liquid and vapor phases: (h) $\mathrm{H}_{2} \mathrm{O}$-rich fluid bubbles in dacitic glass from eastern Manus Basin; (i) $\mathrm{CO}_{2}$-rich fluid inclusion in olivine from Tanna, New Hebrides arc (Vanuatu). Scale bars are $25 \mu \mathrm{m}$. 

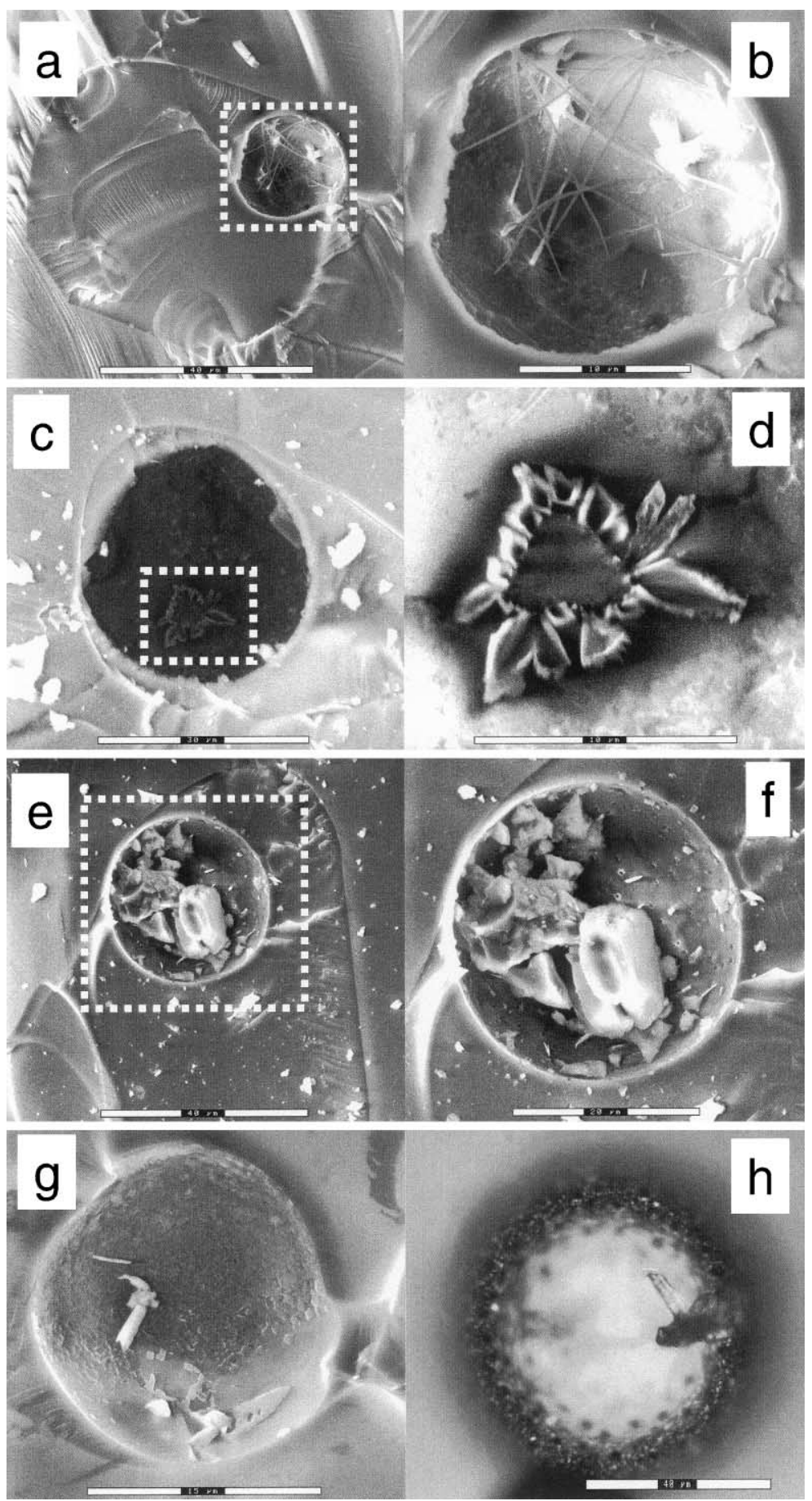

Fig. 3. Microphotographs of broken surfaces of $(\mathrm{a}-\mathrm{g})$ melt inclusions in olivine crystals from the eastern Manus Basin rocks and (h) pillow-rim glass from Macquarie Island showing exposed precipitate-decorated fluid bubbles. (b, $d$ and $f$ ) are enlargements of areas shown on (a, c and e), respectively. 

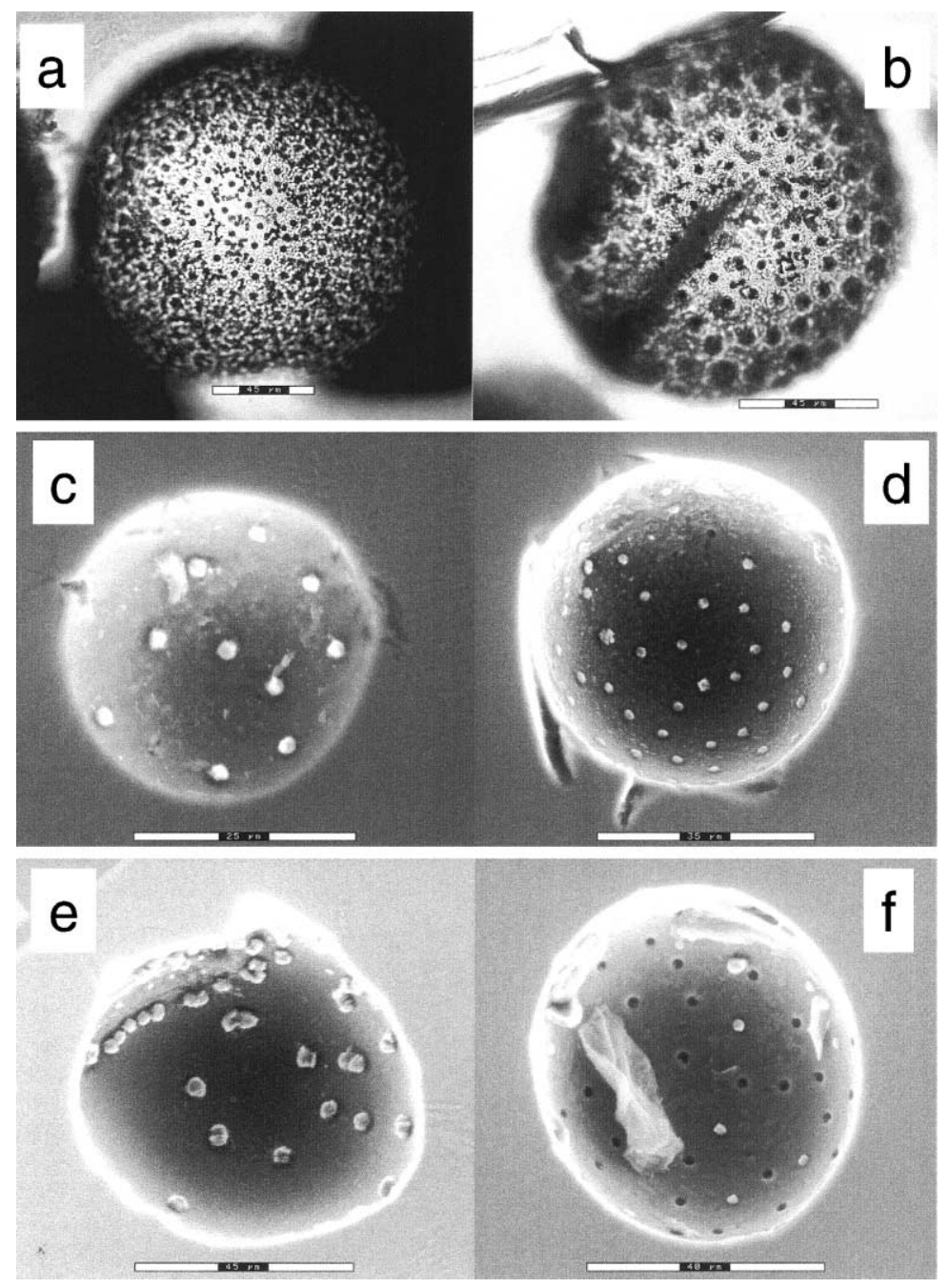

Fig. 4. Precipitates in the form of spherical clusters lining the walls of vesicles in the Macquarie Island glasses. Note regularly spaced hemispherical pits formely filled with precipitates (f). Opaque (a, b) and bright (c) precipitates are Cu-bearing Fe monosulfides, other aggregates are sulfates and carbonates $(\mathrm{d}, \mathrm{e})$.

heterogeneously trapped with a melt, and thus the precipitates can be genetically linked to the immiscible vapor phase.

\subsection{Composition of precipitates}

Phase compositions of precipitates are given in Tables 1 and 2. The predominant phases are carbonates (magnesite, calcite, dolomite, siderite, ankerite, and rare rhodochrosite and nahcolite $\mathrm{NaHCO}_{3}$ ), and their presence is in agreement with vapor $\mathrm{CO}_{2}$ detected in fluid bubbles from all samples studied (Fig. 6) and disordered carbon in some samples (Macquarie Island and New Caledonia). Fluid inclusions with liquid $\mathrm{CO}_{2}$ were rarely observed (except $43^{\circ} \mathrm{N}$ MAR and Hawaii), which points to low pressure $(<2$ kbar) crystallisation. Other important phases identified by laser Raman spectroscopy include sulfates (abundant anhydrite and gypsum, and single grains of barite and anglesite) and sulfides (mainly pyrite, and also chalcopyrite and arsenopyrite). Other mineral phases (e.g., silicates and oxides) are also 


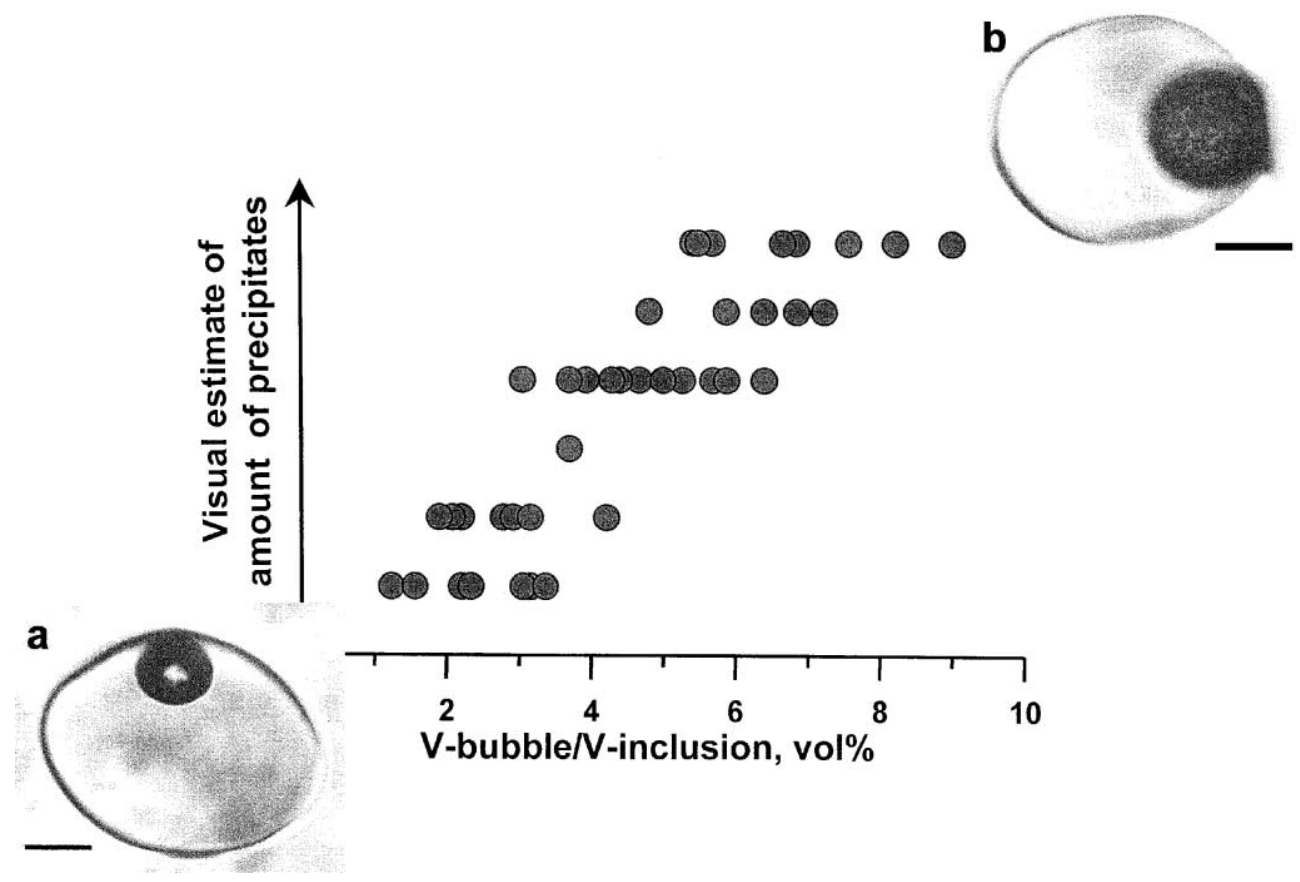

Fig. 5. Correlation between the relative size of fluid bubbles in melt inclusions (eastern Manus Basin tholeiite MD38) and the visual estimate of amount of precipitates in fluid bubbles (see also Kamenetsky et al., 2001). Contrasting types of melt inclusions are illustrated by microphotographs: (a) smaller bubble-minimum precipitates and (b) larger bubble-maximum precipitates. Scale bars are $20 \mu \mathrm{m}$.

present, although they are not ubiquitous, or cannot be detected using Raman spectroscopy (e.g., salts). Strong $\mathrm{Cu} \mathrm{K \alpha}$ peaks, well above background were detected in the EDS spectra of Fe sulfides in vesicles in the MORB glasses. The minimum $\mathrm{Cu}$ concentration is estimated as $1 \mathrm{wt} . \%$, possibly $2-4 \mathrm{wt} . \%$.

Scanning electron microscopy on the breached fluid bubbles in melt inclusions from eastern Manus Basin revealed that bubble contents may change their appearance and phase composition after opening of the bubble (Kamenetsky et al., 2001). For example, immediately after opening, the bubble shown in Fig. $3 \mathrm{e}$ and $\mathrm{f}$ contained a large central grain and amorphous precipitates to the left. However, during the next analytical session, the contents of this cavity looked quite different (Fig. 7). Amorphous precipitates had partly recrystallised into aggregate of $\mathrm{Na}-$ $\mathrm{Ca}$ carbonates, $\mathrm{Na}-\mathrm{Cl}$ (halite) cubes, and $\mathrm{Na}-\mathrm{K}-\mathrm{Ca}$

Table 2

Mineral composition of precipitates inside fluid bubbles in submarine glasses and glassy melt inclusions in olivine phenocrysts

\begin{tabular}{lllll}
\hline Carbonates & Sulphates & Sulphides & Silicates & Other \\
\hline Magnesite $(1-9)$ & Anhydrite $(1,2,4,5)$ & Pyrite $(1,2,4,7,9)$ & Clinoenstatite (4) & Disordered Carbon (2, 8) \\
Calcite $(4,7,9)$ & Gypsum $(4,7,8)$ & Chalcopyrite $(3,4,6)$ & Kalsilite-Nepheline (4) & Brookite (2) \\
Dolomite $(2,9)$ & Barite (4) & Arsenopyrite $(1,2,7)$ & Amphibole (9) & Apatite (4) \\
Siderite $(2)$ & Anglesite (4) & Cu-bearing Fe sulfides (2, 3) & Mica (8) & Halite (4) \\
Ankerite $(1,2)$ & & & & Amorphous phases (1-9) \\
Rhodochrosite (4) & & & & \\
Nahcolite $(4,5)$ & & & &
\end{tabular}

Numbers in parentheses indicate type localities, as in Table 1.

Other mineral species may be present, but have not been detected yet. For example, in the more throughly (more analytical points) studied samples from the eastern Manus basin a greater number of different minerals were found. 


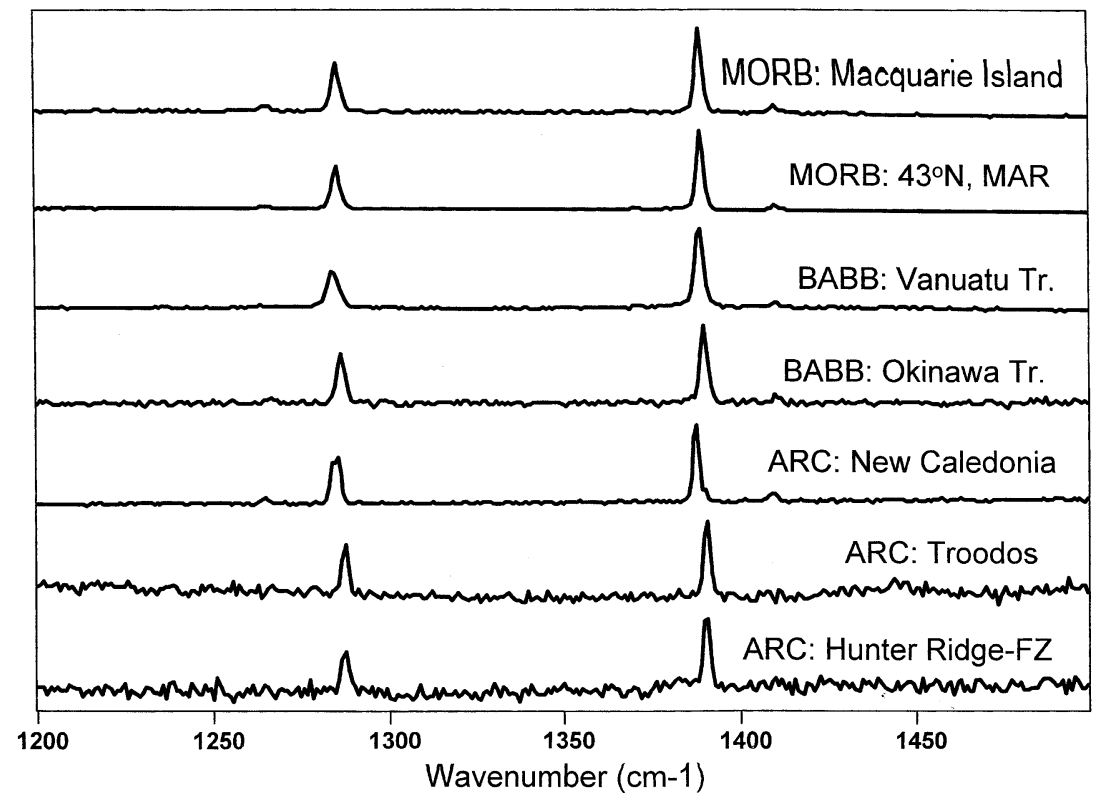

Fig. 6. Raman microprobe spectra showing the presence of $\mathrm{CO}_{2}$ in fluid bubbles in melt inclusions in olivine from different geodynamic settings.
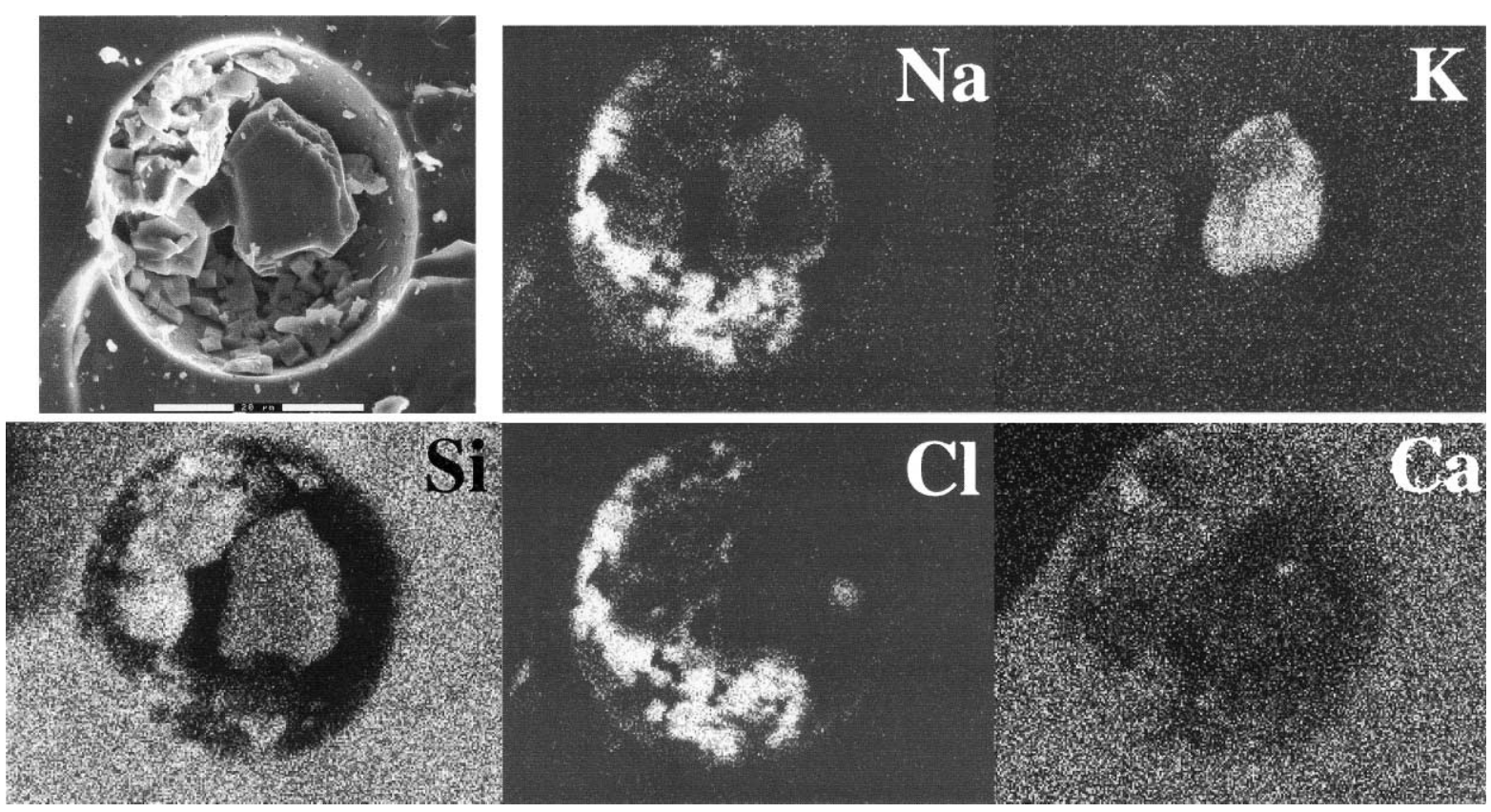

Fig. 7. Amorphous and crystal precipitates in exposed fluid bubble in the glass inclusion in olivine (eastern Manus basin) a few weeks after opening (Kamenetsky et al., 2001). See the same inclusion immediately after opening on Fig. 3e,f. X-ray element distribution maps show the presence of amorphous silicate phases, halite cubes $(\mathrm{Na}$ and $\mathrm{Cl}$ ) and a large crystal comprising kalsilite $(\mathrm{K})$ - and nepheline (Na)-enriched components. 
alumino-silicate phases with $\mathrm{Cl}$-enriched rims, and the central crystal seemed to have turned over on to its flat side. According to X-ray mapping (Fig. 7), this grain shows chemical heterogeneity in terms of $\mathrm{K}$ and $\mathrm{Na}$ content, and its composition corresponds to a kalsilite-nepheline solid solution.

\section{Discussion and conclusions}

\subsection{Origin of precipitates in fluid bubbles}

The mechanism of formation of bubbles in phenocryst-hosted melt inclusions and vapor-filled vesicles in quenched glasses, and the ultimate source of "non-volatile" components forming precipitates lining the walls of the bubbles, are crucial in understanding many aspects of melt/fluid immiscibility, magma degassing, element partitioning between coexisting magma and vapor, and metal availability for related hydrothermal fluids and solutions.

It is generally accepted that degassing of $\mathrm{CO}_{2-}$ enriched fluids from mafic magmas in a variety of tectonic settings commences at high pressures, even in the mantle (e.g., Roedder, 1965). $\mathrm{CO}_{2}$ and other gases with low solubility in silicate magmas (e.g., sulfurous species) prevail in exsolved fluids during magma ascent and crystallisation at pressures $>1$ kbar. This is evident from the composition of fluid inclusions trapped in phenocrysts (Roedder, 1965; Kamenetsky et al., 1986; Coombs and Roedder, 1994; Sobolev and Nikogosian, 1994; Lowenstern, 1995; Yang and Scott, 1996) and gases in vesicles from quenched glasses (Moore et al., 1977; Moore, 1979; Javoy and Pineau, 1991). In contrast, water may dominate in the fluid phase at subsurface pressures, especially in the case of $\mathrm{H}_{2} \mathrm{O}$-enriched subduction-related magmas, as observed in arc-backarc glasses (e.g., Garcia et al., 1979; Danyushevsky et al., 1992; Alt et al., 1993), melt inclusions (Sobolev and Naumov, 1985), emanations from arc volcanoes (Hedenquist and Lowenstern, 1994) and comparison of $\mathrm{H}_{2} \mathrm{O}$ contents in glasses and melt inclusions (Sobolev and Chaussidon, 1996). Thus, most basaltic (for an exception, see Gurenko et al., 1988) and all felsic magmas are fluid-saturated during crystallisation, and produce a volatile phase in the form of fluid bubbles (Bottinga and Javoy, 1990).
These immiscible fluids bubbles were also recorded in our study of the quenched MORB (Fig. 4) and backarc (Fig. 2h) glasses, and individual fluid inclusions in phenocrysts (Fig. 2). The origin of fluid bubbles in the phenocryst-hosted melt inclusions appears to be more complicated, as a bubble can form in the trapped melt during cooling due to differential shrinkage of melt and host mineral (Roedder, 1984). Theoretically, homogeneously trapped melt inclusions should have similar glass-bubble ratios (Anderson and Brown, 1993), with a size of a shrinkage bubble $<5$ vol.\% of an inclusion. However, as can be seen from the eastern Manus boninite (Fig. 5), bubble sizes are often larger than 5 vol.\%, and the relative size of bubbles varies widely in nearby, coeval melt inclusions. The presence in melt inclusions of vapor bubbles larger than shrinkage bubbles is typical of all samples studied. This and the higher density of precipitates in the larger bubbles (Fig. 5, see discussion below) suggest simultaneous entrapment of melt and a separate fluid phase from the heterogeneous magma.

The origin of precipitates inside vapor bubbles is controversial. Sulfide spherules decorating vesicles in quenched submarine glasses (Moore and Calc, 1971; Mathez and Yeats, 1976; Yeats and Mathez, 1976; Moore et al., 1977; Alt et al., 1993) and carbonates in $\mathrm{CO}_{2}$-rich fluid inclusions in mantle and basaltic phenocrysts (Rovetta and Mathez, 1982; Andersen et al., 1984; Sobolev and Nikogosian, 1994) have been interpreted to have formed by reaction of sulfurous or $\mathrm{CO}_{2}$-rich volatiles with elements (e.g., $\mathrm{Fe}, \mathrm{Cu}, \mathrm{Mg}$, $\mathrm{Ca}$, etc.) diffusing from the host melt or crystal. Alternatively, all the required elements were dissolved in the fluid prior to the formation of precipitates (Lowenstern et al., 1991; Solovova et al., 1991; Lowenstern, 1995; Yang and Scott, 1996; de Hoog and van Bergen, 2000). Based on the study of matrix glasses, melt inclusions and their $\mathrm{Cu}$-rich $\mathrm{CO}_{2}$ - and Cl-bearing fluid bubbles from pantellerites Lowenstern et al. (1991) provided strong arguments to support the latter model. We present further evidence in favor of the idea that magmatic vapors have complex compositions.

(1) The density of precipitates is proportional to the relative size of a fluid bubble in melt inclusions (Fig. 5), so the larger bubbles contain more precipitates (also noted by Lowenstern et al., 1991). This is because heterogeneously trapped larger bubbles are 
less "diluted" by the volume contribution from a low-density shrinkage bubble(s).

(2) Fluid inclusions in olivine phenocrysts do not have precipitate compositions different to fluid bubbles entrapped within glass. This argues against a possible compositional effect from the host.

(3) Many precipitates are freestanding within vesicles (Fig. 3b,f,h), which is more likely if the required compounds were supplied from the fluid, not due to diffusion from the outside media.

(4) Some bubbles contain aluminosilicate amorphous and crystalline precipitates (e.g., kalsilitenepheline, Fig. 7; zirconolite in the study by de Hoog and van Bergen, 2000), which are not liquidus phases in the studied rocks.

(5) Although some precipitates (e.g., sulfides) may form at liquidus temperatures, as indicated by their embedding in vesicles walls (Fig. 4), other mineral phases (e.g., carbonates and salts) are only stable below the temperature at which the studied basaltic samples formed $\left(>1100-1200{ }^{\circ} \mathrm{C}\right)$. High quenching temperatures minimize the likelihood of the postentrapment chemical exchange by diffusion.

Some other indirect arguments can be also considered. For example, most mid-ocean ridge and oceanic intraplate magmas are saturated with respect to a sulfide phase at the time of eruption, and immiscible sulfide liquids (globules) actually form. Thus, $\mathrm{Cu}$ is unlikely to be available for diffusion and reaction with fluid phase in the bubbles. Also, it is well established that volcanic sublimates contain a myriad of metallic and non-metallic elements (Naughton et al., 1974; Symonds et al., 1987, 1992; Nriagu, 1989; Hinkley et al., 1999). This combined with the data from meltfluid inclusion (Lowenstern et al., 1991; Heinrich et al., 1992; Lowenstern, 1993, 1994a; Yang and Scott, 1996; Dietrich et al., 1999; Kamenetsky et al., 2001) and experimental (Candela and Holland, 1984; Candela and Piccoli, 1995) studies argues for strong partitioning of certain "non-volatile" elements into vapor.

\subsection{Chemical composition of magmatic fluids}

Formation of precipitates inside vapor bubbles due to sublimation/condensation from magmatic fluids, as implied in the previous section, requires the presence of significant quantities of various components. These can be inferred from the compositions of vapor and precipitates. Carbon dioxide, detected by Raman spectroscopy in many bubbles from all basaltic samples (Fig. 6), is the most important gaseous phase. This is confirmed by ubiquitous carbonate minerals and disordered carbon among precipitates (Table 2). Although gases other than $\mathrm{CO}_{2}$ were not specifically investigated during Raman analysis, we are confident that various sulfurous species (e.g., $\mathrm{SO}_{2}$ and $\mathrm{H}_{2} \mathrm{~S}$ ) and water are/were present. Sulfur is presently stored in sulfates and sulfides, and water is a component of gypsum, nahcolite and silicates (mica and amphibole) - see Table 2. The result of this work - prevalence of $\mathrm{CO}_{2}$ in magmatic fluids derived from mafic magmas in different tectonic settings - is in agreement with the results of empirical studies (e.g., Roedder, 1965; Moore, 1979; Javoy and Pineau, 1991; Williams et al., 1992; Anderson and Brown, 1993; Seward and Kerrick, 1996, see also references in Dixon and Stolper, 1995) and experimental data on the strong partitioning of $\mathrm{CO}_{2}$ relative to $\mathrm{H}_{2} \mathrm{O}$ into fluids in equilibrium with vapor-saturated melts (e.g., Dixon and Stolper, 1995). Even in $\mathrm{H}_{2} \mathrm{O}$-enriched melts $\left(\sim 2\right.$ wt. $\% \mathrm{H}_{2} \mathrm{O}$, subduction-related backarc and island arc samples in our study), crystallising at pressures $\geq 1 \mathrm{kbar}$, the solubility of $\mathrm{CO}_{2}$ in vapor is significantly higher than that of $\mathrm{H}_{2} \mathrm{O}$, so $\mathrm{CO}_{2}$ makes up at least $60 \mathrm{~mol} \%$ of the vapor (Dixon and Stolper, 1995), although almost pure $\mathrm{CO}_{2}$ fluids can be also found (Fig. 2i). For magmas with lesser $\mathrm{H}_{2} \mathrm{O}$ abundances (enriched MORB, OIB) the proportion of $\mathrm{CO}_{2}$ in vapor is even higher, reaching $100 \%$ in depleted MORB. Degassing of $\mathrm{H}_{2} \mathrm{O}$ increases with pressure release and becomes very significant at the pressures of magma emplacement (e.g., Dixon and Stolper, 1995). This is evident from comparison of $\mathrm{H}_{2} \mathrm{O}$ contents of melt inclusions (enriched) and matrix glasses (depleted) from subduction-related settings, including our samples of boninites and arc tholeiites from the Hunter Ridge (Sobolev and Chaussidon, 1996), and may be observed in the tube-shaped bubbles in matrix glasses (Fig. 2h, see also Danyushevsky et al., 1992) and fluid bubbles in melt inclusions entrapped in shallow ( $<1 \mathrm{kbar})$ crystallised phenocrysts (Kamenetsky et al., 1986).

The solubility of non-gaseous components (e.g., Si, $\mathrm{Al}$, etc.) in $\mathrm{H}_{2} \mathrm{O}-\mathrm{CO}_{2}$ vapor has been experimentally shown to be very low at high ( $>5 \mathrm{kbar}$ ) pressures (see review in Eggler, 1987). In contrast, this work 
and published data (Moore and Calc, 1971; Yeats and Mathez, 1976; Moore et al., 1977; Lowenstern et al., 1991; Lowenstern, 1995; Yang and Scott, 1996; Kamenetsky et al., 2001) on low pressure $(<5$ kbar $)$ $\mathrm{CO}_{2}$-bearing fluid bubbles suggest that sublimation/ condensation of precipitates requires the presence of elements such as $\mathrm{Si}, \mathrm{Al}, \mathrm{Na}, \mathrm{K}, \mathrm{Fe}, \mathrm{Mn}, \mathrm{Cr}, \mathrm{Ni}, \mathrm{Cu}$, $\mathrm{Ca}, \mathrm{Mg}, \mathrm{Ba}, \mathrm{Pb}, \mathrm{Zn}, \mathrm{Cl}$, and $\mathrm{As}$ in magmatic fluids. This apparent conflict between experimental and empirical results can be tentatively attributed to effects of some components in natural systems (e.g., Cl, F, S, B) enhancing solubility of other elements, and to a significant discrepancy in pressure of vapor-melt equilibria in both systems. For example, experiments by Wendlandt and Harrison (1979) demonstrated that the solubility of rare earth elements (REE) in $\mathrm{CO}_{2}$ vapor strongly increases with reducing pressure, and should reach a maximum at near-surface pressures, especially for light REE. According to these experimental data, enrichment of REE in the $\mathrm{CO}_{2}$ vapor at 5 kbar is three to four orders of magnitute higher than that in $\mathrm{H}_{2} \mathrm{O}$ vapor at comparable pressure, possibly due to strong carbonate complexing. The significant role of other ligands in the transport of various metals in the fluid phase (e.g., chloride complexing) is also not be neglected (e.g., Candela and Holland, 1984; Symonds et al., 1988, 1994; Candela and Piccoli, 1995; Webster, 1997; Webster et al., 1999).

\subsection{Metals in fluid fluxes from basaltic magmas}

It follows from the above discussion that the vapor/ melt immiscibility and subsequent degassing may have a profound effect on the composition of a crystallizing basaltic magma. While major petrogenetic elements are influenced by changing cotectic relationships due to $\mathrm{H}_{2} \mathrm{O}$ loss, minor and trace elements, otherwise highly to moderately compatible with a melt, can be even more compatible with the $\mathrm{C}-\mathrm{H}-\mathrm{S}-\mathrm{Cl}$ fluids. This has been demonstrated in the study of the basalt-andesitedacite series from the eastern Manus basin, near PACMANUS hydrothermal field (Kamenetsky et al., 2001). Ore-forming metals $(\mathrm{Cu}, \mathrm{Zn}$ and $\mathrm{Pb})$ and water abundances in this comagmatic suite show very different behavior during the evolution toward felsic compositions, with $\mathrm{Zn}$ and $\mathrm{H}_{2} \mathrm{O}$ reaching maximum concentrations in andesitic magma, $\mathrm{Cu}$ depletion in felsic magmas compared to basalts, and $\mathrm{Pb}$ acting as moder- ately incompatible element in all melt compositions. In the absence of immiscible sulfide melt, decoupling of $\mathrm{Cu}, \mathrm{Zn}$ and $\mathrm{Pb}$ during magma fractionation and degassing implies strong $\mathrm{Cu}$ partitioning into fluid. Similar examples of metal partitioning in fractionating magmas from different tectonic settings are given in a number of detailed studies by Doe $(1994,1995)$ and Stanton (1994).

What is the metal content of magma-derived fluids? According to estimation given by Yang and Scott (1996), it can be very high (e.g., 2.3 wt.\% $\mathrm{Zn}$ and 7.2 wt.\% $\mathrm{Cu}$ ). We present here a simple calculation from the $\mathrm{CO}_{2}$-bearing vesicles in MORB glasses, in which the size and spacing of the sulfide clusters are remarkably constant (Fig. 4 a,b). The quantity of sulfide is $6-10$ wt.\% based on $0.3-0.5$ vol. $\%$ of sulfides (this work and Moore et al. (1977)), the maximum density of the trapped fluid $\left(0.2 \mathrm{~g} / \mathrm{cm}^{3}\right.$, Moore et al., 1977) and the density of sulfide $\left(4.6 \mathrm{~g} / \mathrm{cm}^{3}\right)$. If the sulfide contains only $1 \mathrm{wt} . \% \mathrm{Cu}$, entirely sublimated from the fluid, then the minimum $\mathrm{Cu}$ content in the fluid was $600-1000 \mathrm{ppm}$ (comparable values were estimated by Lowenstern (1993) for the pre-eruptive fluid in the Valley of Ten Thousand Smokes magmas), significantly higher than in the coexisting basaltic melt $(<100 \mathrm{ppm})$. Note, that our approximation may build up to several thousands ppm if $\mathrm{Cu}$ abundances in the bubble-hosted sulfides are higher than 1 wt.\% (e.g., 4-7 wt.\%, Moore and Calc, 1971).

An important consequence of open system degassing from basaltic magmas can be the transport of fluid and related trace elements into overlying more silicic magmas in the form of upwelling fluid bubbles (e.g., Lowenstern, 1994b). The presence of excessive volatiles in felsic magmas is well documented in studies of recent volcanic eruptions (e.g., Luhr et al., 1984; Anderson et al., 1989; Andres et al., 1991; Westrich and Gerlach, 1992; Williams et al., 1992; Hattori, 1993; Allard et al., 1994; Gerlach et al., 1994; Wallace and Gerlach, 1994). However, quantitative constraints on the metal supply associated with fluid fluxes from mafic magmas, and metal deposition associated with felsic magmas, are required. The present study of magmatic fluid bubbles and their precipitates provides a methodology to refine the ultimate sources and budget of chemicals in the formation of magmatic derived porphyry and volcanic hosted massive sulfide deposits. 


\section{Acknowledgements}

We are grateful to M. Kamenetsky, S. Stephens, D. Steele, E. Bastrakov, G. Yaxley and F. Brink for their help with sample preparation and different analyses. Numerous discussions with S. Eggins, M. Solomon, R. Large, W. Herrmann and G. Yaxley helped to refine the conclusions. We thank R.A. Binns and S.D. Scott (cruise co-chiefs) and the crew of the R.V. Franklin for recovery of the Manus Basin samples and permission to publish the associated analytical results in this paper. Reviews from anonymous referees are gratefully acknowledged. This study was supported by an Australian Research Fellowship and Grant to VSK and by the Australian Research Council's Research Centres Program.

\section{References}

Allard, P., Carbonnelle, J., Métrich, N., Loyer, H., Zettwoog, P., 1994. Sulphur output and magma degassing budget of Stromboli volcano. Nature 368, 326-330.

Alt, J.C., Shanks, W.C., Jackson, M.C., 1993. Cycling of sulfur in subduction zones: the geochemistry of sulfur in the Mariana Island Arc and back-arc trough. Earth Planet. Sci. Lett. 119, 477-494.

Andersen, T., O'Reilly, S.Y., Griffin, W.L., 1984. The trapped fluid phase in upper mantle xenoliths from Victoria, Australia; implications for mantle metasomatism. Contrib. Mineral. Petrol. 88, $72-85$.

Anderson Jr., A.T., Brown, G.G., 1993. $\mathrm{CO}_{2}$ contents and formation pressures of some Kilauean melt inclusions. Am. Mineral. 78, 794-803.

Anderson, A.T., Newman, S., Williams, S.N., Druitt, T.H., Skirius, C., Stolper, E., 1989. $\mathrm{H}_{2} \mathrm{O}, \mathrm{CO}_{2}, \mathrm{Cl}$ and gas in Plinian and ash flow Bishop rhyolite. Geology 17, 221-225.

Andres, R.J., Rose, W.I., Kyle, P.R., de Silva, S., Francis, P., Gardeweg, M., Moreno Roa, H., 1991. Excessive sulfur dioxide emissions from Chilean volcanoes. J. Volcanol. Geotherm. Res. 46, 323-329.

Binns, R.A., Scott, S.D., 1993. Actively forming polymetallic sulfide deposits associated with felsic volcanic rocks in the eastern Manus back-arc basin, Papua New Guinea. Econ. Geol. 88, 2226-2236.

Bottinga, Y., Javoy, M., 1990. Mid-ocean ridge basalt degassing: bubble nucleation. J. Geophys. Res. 95, 5125-5131.

Cameron, W.E., 1989. Contrasting boninite-tholeiite associations from New Caledonia. In: Crawford, A.J. (Ed.), Boninites. Unwin Hyman, London, pp. 314-338.

Candela, P.A., Holland, H.D., 1984. The partitioning of copper and molybdenum between silicate melts and aqueous fluids. Geochim. Cosmochim. Acta 48, 373-380.
Candela, P.A., Piccoli, P.M., 1995. Model ore-metal partitioning from melts into vapor and vapor/brine mixtures. In: Thompson, J.F.H. (Ed.), Magmas, Fluids, and Ore Deposits. Mineral. Assoc. Canada Short Course Series, pp. 101-127.

Coombs, D.S., Roedder, E., 1994. On the significance of $\mathrm{CO}_{2}$ inclusions in plagioclase microphenocrysts in tholeiite from Moeraki, New Zealand. Bull. Volcanol. 56, 23-28.

Danyushevsky, L.V., Sobolev, A.V., Kononkova, N.N., 1992. Methods of studing magma inclusions in minerals during investigations on water-bearing primitive mantle melts (Tonga trench boninites). Geochem. Int. 29, 48-62.

de Hoog, J.C.M., van Bergen, M.J., 2000. Volatile-induced transport of HFSE, REE, Th and $U$ in arc magmas: evidence from zirconolite-bearing vesicles in potassic lavas of Lewotolo volcano (Indonesia). Contrib. Mineral. Petrol. 139, 485-502.

Dietrich, A., Lehmann, B., Wallianos, A., Traxel, K., 1999. High copper and silver abundances in melt inclusions of Bolivian tin porphyry systems. In: Stanley, C.J. (Ed.), Mineral Deposits: Processes to Processing. A.A. Balkema, Rotterdam, pp. 337-340.

Dixon, J.E., Stolper, E.M., 1995. An experimental study of water and carbon dioxide solubilities in Mid-Ocean Ridge basaltic liquids. Part II: Application to degassing. J. Petrol. 36, 1633-1646.

Doe, B.R., 1994. Zinc, copper, and lead in mid-ocean ridge basalts and the source rock control on $\mathrm{Zn} / \mathrm{Pb}$ in ocean-ridge hydrothermal deposits. Geochim. Cosmochim. Acta 58, 2215-2223.

Doe, B.R., 1995. Zinc, copper, and lead geochemistry of oceanic igneous rocks-ridges, islands and arcs. Int. Geol. Rev. 37, $379-420$.

Eggler, D.H., 1987. Solubility of major and trace elements in mantle metasomatic fluids: experimental constraints. In: Menzies, M.A., Hawkesworth, C.J. (Eds.), Mantle Metasomatism. Academic Press, London, pp. 21-41.

Garcia, M.O., Liu, N.W.K., Muenow, D.W., 1979. Volatiles in submarine volcanic rocks from the Mariana island arc and trough. Geochim. Cosmochim. Acta 43, 305-312.

Gerlach, T.M., Westrich, H.R., Casadevall, T.J., 1994. Vapor saturation and accumulation in magmas of the 1989-1990 eruption of Redoubt Volcano, Alaska. J. Volcanol. Geotherm. Res. 62, $317-337$.

Gurenko, A.A., Sobolev, A.V., Polyakov, A.I., Kononkova, N.N., 1988. Primary melt of rift tholeiites of Iceland: composition and conditions of crystallization. Trans. (Doklady) USSR Acad. Sci. 301, 109-113.

Hattori, K., 1993. High-sulfur magma, a product of fluid discharge from underlying mafic magma: evidence from Mount Pinatubo, Philippines. Geology 21, 1083-1086.

Hedenquist, J.W., Lowenstern, J.B., 1994. The role of magmas in the formation of hydrothermal ore deposits. Nature 370, 519-527.

Hedenquist, J.W., Simmons, S.F., Giggenbach, W.F., Eldridge, C.S., 1993. White Island, New Zealand, volcanic-hydrothermal system represents the geochemical environment of high-sulfidation $\mathrm{Cu}$ and $\mathrm{Au}$ ore deposition. Geology 21, 731-734.

Hedenquist, J.W., Aoki, M., Shinohara, H., 1994. Flux of volatiles and ore-forming metals from the magmatic-hydrothermal system of Satsuma Iwojima Volcano. Geology 22, 585-588.

Heinrich, C.A., Ryan, C.G., Mernagh, T.P., Eadington, P.J., 1992. Segregation of ore metals between magmatic brine and vapor: a 
fluid inclusion study using PIXE microanalysis. Econ. Geol. 87, $1566-1583$.

Hinkley, T.K., Lamothe, P.J., Wilson, S.A., Finnegan, D.L., Gerlach, T.M., 1999. Metal emissions from Kilauea, and a suggested revision of the estimated worldwide metal output by quiescent degassing of volcanoes. Earth Planet. Sci. Lett. 170, $315-325$.

Javoy, M., Pineau, F., 1991. The volatiles record of a "popping" rock from the Mid-Atlantic Ridge at $14^{\circ} \mathrm{N}$ : chemical and isotopic composition of gas trapped in the vesicles. Earth Planet. Sci. Lett. 107, 598-611.

Kamenetsky, V., Sobolev, A., Clocchiatti, R., Metrich, N., 1986. Première estimation de la teneur en eau du magma de l'Etna à partir de l'étude des inclusions vitreuses et fluides. C.R. Acad. Sci. Paris 302, 1069-1074.

Kamenetsky, V.S., Eggins, S.M., Crawford, A.J., Green, D.H., Gasparon, M., Falloon, T.J., 1998. Calcic melt inclusions in primitive olivine at $43^{\circ} \mathrm{N}$ MAR: evidence for melt-rock reaction/melting involving clinopyroxene-rich lithologies during MORB generation. Earth Planet. Sci. Lett. 160, 115-132.

Kamenetsky, V.S., Everard, J.L., Crawford, A.J., Varne, R., Eggins, S.M., Lanyon, R., 2000. Enriched end-member of primitive MORB melts: petrology and geochemistry of glasses from Macquarie Island (SW Pacific). J. Petrol. 41, 411-430.

Kamenetsky, V.S., Binns, R.A., Gemmell, J.B., Crawford, A.J., Mernagh, T.P., Maas, R., Steele, D., 2001. Parental basaltic melts and fluids in eastern Manus backarc basin: implications for hydrothermal mineralisation. Earth Planet. Sci. Lett. 184, $685-702$.

Lowenstern, J.B., 1993. Evidence for a copper-bearing fluid in magma erupted at the Valley of Ten Thousand Smokes, Alaska. Contrib. Mineral. Petrol. 114, 409-421.

Lowenstern, J.B., 1994a. Chlorine, fluid immiscibility, and degassing in peralkaline magmas from Pantelleria, Italy. Am. Mineral. 79, 353-369.

Lowenstern, J.B., 1994b. Dissolved volatile concentrations in an ore-forming magma. Geology 22, 893-896.

Lowenstern, J.B., 1995. Applications of silicate-melt inclusions to the study of magmatic volatiles. In: Thompson, J.F.H. (Ed.), Magmas, Fluids, and Ore Deposits. Mineral. Assoc. Canada Short Course Series, pp. 71-99.

Lowenstern, J.B., Mahood, G.A., Rivers, M.L., Sutton, S.R., 1991. Evidence for extreme partitioning of copper into a magmatic vapor phase. Science 252, 1405-1409.

Luhr, J.F., Carmichael, I.S.E., Varekamp, J.C., 1984. The 1982 eruptions of El Chichon volcano, Chiapas, Mexico: mineralogy and petrology of the anhydrite-bearing pumices. J. Volcanol. Geotherm. Res. 23, 69-108.

Maillet, P., Ruellan, E., Gerard, M., Person, A., Bellon, H., Cotten, J., Joron, J.-L., Nakada, S., Price, R.C., 1995. Tectonics, magmatism, and evolution of the New Hebrides backarc troughs (southwest Pacific). In: Taylor, B. (Ed.), Backarc Basins: Tectonics and Magmatism. Plenum, New York, pp. 177-235.

Mathez, E.A., Yeats, R.S., 1976. Magmatic sulfides in basalt glass from DSDP Hole 319A and Site 320, Nazca Plate. In: Yeats, R.S., Hart, S.R. (Eds.), Initial Rep. DSDP. US Gov. Print Office, Washington, DC, pp. 363-373.
Moore, J.G., 1979. Vesicularity and $\mathrm{CO}_{2}$ in mid-ocean ridge basalt. Nature 282, 250-253.

Moore, J.G., Calc, L., 1971. Sulfide spherules in vesicles of dredged pillow basalt. Am. Mineral. 56, 476-488.

Moore, J.G., Batchelder, J.N., Cunningham, C.G., 1977. $\mathrm{CO}_{2}$-filled vesicles in mid-ocean basalt. J. Volcanol. Geotherm. Res. 2, 309-327.

Naughton, J.J., Lewis, V.A., Hammond, D., Nishimoto, D., 1974. The chemistry of sublimates collected directly from lava fountains at Kilauea Volcano, Hawaii. Geochim. Cosmochim. Acta $38,1679-1690$.

Nriagu, J.O., 1989. A global assessment of natural sources of atmospheric trace metals. Nature 338, 47-49.

Portnyagin, M.V., Danyushevsky, L.V., Kamenetsky, V.S., 1997. Coexistence of two distinct mantle sources during formation of ophiolites: a case study of primitive pillow-lavas from the lowest part of the volcanic section of the Troodos Ophiolite, Cyprus. Contrib. Mineral. Petrol. 128, 287-301.

Roedder, E., 1965. Liquid $\mathrm{CO}_{2}$ inclusions in olivine-bearing nodules and phenocrysts from basalts. Am. Mineral. 50, 1746-1782.

Roedder, E., 1984. Fluid inclusions. Reviews in Mineralogy, Vol. 12 Book Crafters, Michigan.

Rovetta, M.R., Mathez, E.A., 1982. Magnesite and other minerals in fluid inclusions in a lherzolite xenolith from an alkali basalt. Terra Cognita 2, 229.

Seward, T.M., Kerrick, D.M., 1996. Hydrothermal $\mathrm{CO}_{2}$ emission from the Taupo Volcanic Zone, New Zealand. Earth Planet. Sci. Lett. $139,105-113$.

Shinjo, R., Chung, S.-L., Kato, Y., Kimura, M., 1999. Geochemical and $\mathrm{Sr}-\mathrm{Nd}$ isotopic characteristics of volcanic rocks from the Okinawa Trough and Ryukyu Arc: implications for the evolution of a young, intracontinental back arc basin. J. Geophys. Res. 104, 10591-10608.

Sigurdsson, I.A., Kamenetsky, V.S., Crawford, A.J., Eggins, S.M., Zlobin, S.K., 1993. Primitive island arc and oceanic lavas from the Hunter Ridge-Hunter Fracture zone. Evidence from glass, olivine and spinel compositions. Mineral. Petrol. 47, 149-169.

Sobolev, A.V., Chaussidon, M., 1996. $\mathrm{H}_{2} \mathrm{O}$ concentrations in primary melts from supra-subduction zones and mid-ocean ridges: implications for $\mathrm{H}_{2} \mathrm{O}$ storage and recycling in the mantle. Earth Planet. Sci. Lett. 137, 45-55.

Sobolev, A.V., Naumov, V.B., 1985. First direct proof of the presence of water in ultramafic melts and their estimated water content. Trans. (Doklady) USSR Acad. Sci. 280, 102-105.

Sobolev, A.V., Nikogosian, I.K., 1994. Petrology of long-lived mantle plume magmatism: Hawaii, Pacific and Reunion Island, Indian Ocean. Petrology 2, 111-144.

Sobolev, A.V., Portnyagin, M.V., Dmitriev, L.V., Tsameryan, O.P., Danyushevsky, L.V., Kononkova, N.N., Shimizu, N., Robinson, P.T., 1993. Petrology of ultramafic lavas and associated rocks of the Troodos massif, Cyprus. Petrology 1, 331-361.

Solovova, I.P., Girnis, A.V., Naumov, V.B., Kovalenko, V.I., Guzhova, A.V., 1991. Mechanism of degassing of silicic magmas: formation of two fluid phases during pantellerite crystallisation, Pantelleria. Trans. (Doklady) USSR Acad. Sci. 320, 982-985. 
Stanton, R.L., 1994. Ore elements in arc lavas. Oxford Monographs on Geology and Geophysics, vol. 29. Clarendon Press, Oxford. Symonds, R.B., Rose, W.I., Reed, M.H., Lichte, F.E., Finnegan, D.L., 1987. Volatilization, transport and sublimation of metallic and non-metallic elements in high temperature gases at Merapi Volcano, Indonesia. Geochim. Cosmochim. Acta 51, $2083-2101$

Symonds, R.B., Rose, W.I., Reed, M.H., 1988. Contribution of Cland F-bearing gases to the atmosphere by volcanoes. Nature $334,415-418$.

Symonds, R.B., Reed, M.H., Rose, W.I., 1992. Origin, speciation, and fluxes of trace-element gases at Augustine volcano, Alaska: insights in magma degassing and fumarolic processes. Geochim. Cosmochim. Acta 56, 633-657.

Symonds, R.B., Rose, W.I., Bluth, G.J.S., Gerlach, T.M., 1994. Volcanic-gas studies: methods, results, and applications. In: Carroll, M.R., Holloway, J.R. (Eds.), Volatiles in Magmas. Mineralogical Society of America, Washington, DC, pp. 1-66.

Tatsumi, Y., Eggins, S., 1995. Subduction zone magmatism. Frontiers in Earth Sciences. Blackwell.

Wallace, P.J., Gerlach, T.M., 1994. Magmatic vapor source for sulfur dioxide released during volcanic eruptions: evidence from Mount Pinatubo. Science 265, 497-499.
Webster, J.D., 1997. Exsolution of magmatic volatile phases from Cl-enriched mineralizing granitic magmas and implications for ore metal transport. Geochim. Cosmochim. Acta 61, 1017-1029.

Webster, J.D., Kinzler, R.J., Mathez, E.A., 1999. Chloride and water solubility in basalt and andesite melts and implications for magmatic degassing. Geochim. Cosmochim. Acta 63, 729-738.

Wendlandt, R.F., Harrison, W.J., 1979. Rare earth partitioning between immiscible carbonate and silicate liquids and $\mathrm{CO}_{2}$ vapor: results and implications for the formation of light rare earthenriched rocks. Contrib. Mineral. Petrol. 69, 409-419.

Westrich, H.R., Gerlach, T.M., 1992. Magmatic gas source for the stratospheric $\mathrm{SO}_{2}$ cloud from the June 15, 1991 eruption of Mount Pinatubo. Geology 20, 867-870.

Williams, S.N., Schaefer, S.J., Calvache, M.L., Lopez, D., 1992. Global carbon dioxide emission to the atmosphere by volcanoes. Geochim. Cosmochim. Acta 56, 1765-1770.

Yang, K.H., Scott, S.D., 1996. Possible contribution of a metal-rich magmatic fluid to a sea-floor hydrothermal system. Nature 383, $420-423$.

Yeats, R.S., Mathez, E.A., 1976. Decorated vesicles in deep-sea basalt glass, eastern Pacific. J. Geophys. Res. 81, 4277-4284. 